Results There were 100 patients; 88 males, 12 females. Age range was 1-68 years. Patients in 3rd and 4th decades of life accounted for $69 \%$. Twenty three percent were students, $21 \%$ civil servants, $13 \%$ each were traders and drivers and $7 \%$ were policemen/force men. Ninety one percent had intentional gunshots; out of which $66 \%$ were due to armed robbery attack, $9 \%$ from law enforcement agents, $6 \%$ from communal clash and $5 \%$ from cultists. Armed robbers shot $48 \%$ of patients on the roads, $13 \%$ at home and $3 \%$ at their shops. Law enforcement agents intentionally shot $5 \%$ of patients on the roads. Dane gun was used on $73 \%$ of patients and rifle on $22 \%$. Four percents died; 2 from sepsis and 1 from haemorrhage.

Conclusion Gunshot injuries are suffered mainly by males in the 21-40 years age group who are family bread winners. Most of the injuries were sustained while commuting on the roads from shots fired by armed robbers. There is need for improved security and civil protection on our roads. Reducing unemployment will reduce armed robbery attack.

\title{
0879 GUNSHOTS; ANOTHER CAUSE OF INJURIES ON OUR ROADS
}

UCInyang*, BA Solagberu, COfoegbu Correspondence:DepartmentofOrthopaedics/ Trauma, University Teaching Hospital, Adoekiti, Ekiti State, Nigeria

\subsection{6/ip.2010.029215.879}

Objective Recent armed conflicts in West Africa and increasing ethno-religious crisis in Nigeria have made gunshot injuries the second leading cause of trauma deaths in the sub-region. This study was done to determine the predisposing factors, types of guns used and circumstances surrounding injuries sustained.

Material and Methods Prospective study over 3-years of gunshot-injured patients seen at the emergency unit of a university hospital in Nigeria was done. Age, gender, occupation, circumstances of gunshot, place of injury, type of gun used and outcome (dead or alive) were studied. 